\title{
EDUKASI KADER KESEHATAN DALAM PENGELOLAAN PASIEN DIABETES MELITUS PADA MASA PANDEMIC COVID-19
}

\author{
Santi Herlina ${ }^{1}$, Duma Lumban Tobing ${ }^{2}$, Evin Novianti ${ }^{1}$ \\ ${ }^{1}$ Jurusan Keperawatan, Universitas Pembangunan Nasional Veteran Jakarta \\ Surel :santiherlina@upnvj.ac.id \\ ${ }^{2}$ Jurusan Keperawatan, Universitas Pembangunan Nasional Veteran Jakarta \\ Surel : duma.tobing@upnvj.ac.id \\ ${ }^{2}$ Jurusan Keperawatan, Universitas Pembangunan Nasional Veteran Jakarta \\ Surel: evinnovianti@upnvj.ac.id
}

\begin{abstract}
Corona Virus Disease 19 (Covid-19) was declared by WHO as a global pandemic outbreak in March 2020. Even the number of cases of Covid-19 in Indonesia in July 2021 had shown a significant graphic increase. The group that has a risk of severe symptoms that arise from this COVID-19 disease is one of them in people who have a history of diabetes mellitus. One of the high mortality due to this disease is due to the cormobid suffered by these patients. Diabetes mellitus is the highest comorbid and the second cause of death in cases of covid 19. There is a need for the role of the community in controlling this disease. The community needs to be taught how to control cormobid disease so as not to be exposed to covid 19. One form of activity that can be carried out is to empower health cadres that have been formed in the community, namely Pos Bindu Dahlia Senja, Limo Village, Depok City. The purpose of this community service activity is so that the spread of the covid 19 disease can be controlled, especially to avoid risk groups with cormobid diabetes mellitus. The method of implementing this activity is by counseling and demonstration. The media used are educational posters that will be used by cadres in providing education through social media. The result of this activity is that there is an increase in the ability of cadres by $75 \%$ in understanding the educational process that will be given to diabetes mellitus patients in their environment during the covid 19 pandemic. to patients who have a history of diabetes mellitus even in the COVID-19 pandemic situation.
\end{abstract}

\section{Keywords: Covid 19, Diabetes Mellitus, Education, Cadre}

\begin{abstract}
ABSTRAK
Corona Virus Disease 19 (Covid-19) dinyatakan oleh WHO sebagai wabah pandemic global pada pada Maret 2020. Angka kejadian Covid-19 di Indonesia pun pada bulan Juli 2021 sempat menunjukan peningkatan grafik yang siginifikan. Kelompok yang memiliki resiko beratnya gejala yang muncul dari penyakit covid-19 ini adalah salah satunya pada orang orang yang memiliki riwayat diabetes mellitus. Salah satu tingginya kematian karena penyakit ini adalah karena cormobid yang diderita oleh pasien tersebut. Diabetes mellitus menjadi cormorbid tertinggi dan peyebab kematian kedua pada kasus covid 19. Perlu adanya peran masyarakat dalam pengendalian penyakit ini. Masyarakat perlu diajarkan bagaimana mengendalikan penyakit cormobid agar tidak terkena paparan covid 19. Salah satu bentuk kegiatan yang dapat dilakukan adalah dengan memberdayakan kader kesehatan yang sudah terbentuk dimasyarakat yaitu Pos Bindu Dahlia Senja Kelurahan Limo Kota Depok. Tujuan dari kegiatan pengabdian kepada masyarakat ini adalah agar penyebaran penyakit covid 19 ini dapat terkendali terutama terhindarnya kelompok berisiko dengan cormobid diabetes mellitus. Metode pelaksanaan kegiatan ini adalah dengan penyuluhan dan demonstrasi. Media yang digunakan adalah poster edukasi yang akan digunakan kader dalam memberikan edukasi melalui media sosial. Hasil dari kegiatan ini terdapatnya peningkatan kemampuan kader sebesar $74,55 \%$ dalam memahami proses edukasi yang akan diberikan kepada pasien diabetes mellitus di lingkungannya pada masa pandemic covid 19. Kesimpulannya pelatihan ini memiliki pengaruh yang baik dalam meningkatkan pengetahuan dan kemampuan kader sehingga diharapkan kader dapat tetap memberikan edukasi kepada pasien yang memiliki riwayat diabetes mellitus walaupun dalam situasi pandemic covid 19 .
\end{abstract}

Kata kunci : Covid 19, Diabetes Mellitus, Edukasi, Kader

\section{PENDAHULUAN}

Corona Virus Disease 19 (Covid-19) dinyatakan oleh WHO sebagai wabah pandemic global pada pada Maret 2020. Yang dkk., (2020) mengungkapkan bahwa kematian terbanyak pada 
Seminar Nasional Hasil Penelitian dan Pengabdian Kepada Masyarakat 2021

Pengembangan Ekonomi Bangsa Melalui Inovasi Digital Hasil Penelitian dan

Pengabdian Kepada Masyarakat

Jakarta, 21 Oktober 2021

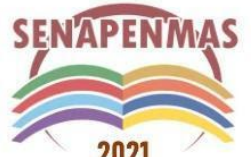

2021

pasien konfirmasi ada pada usia diatas 60 tahun dengan komplikasi ARDS dan penyakit komorbid lainnya, seperti gangguan ginjal akut, diabetes melitus, penyakit kardiovaskular, dan gangguan fungsi hati. Indonesia memiliki angka kejadian Covid-19 per tanggal 7 September 2021 terkonfirmasi positif sebesar 4. 133.433 jiwa dengan kasus meninggal sebesar 136.473 jiwa. Rata - rata kasus meninggal pada pasien dengan penyakit penyerta atau cormobid. Tiga angka cormorbid tertinggi pada kasus covid 19 adalah Hipetensi sebesar 50\%, diabetes mellitus $37,2 \%$, penyakit jantung $16,6 \%$. Tertinggi kasus covid-19 meninggal dengan cormorbid secara berurutan adalah hipertensi, diabetes mellitus dan penyakit jantung (covid19.go.id). Diabetes mellitus merupakan salah satu penyakit tertinggi di Indonesia. Menurut Riset Kesehatan Dasar tahun 2018 sebesar 4,2\% kematian pada kelompok umur 15-44 tahun di daerah perkotaan disebabkan oleh diabetes melitus dan juga penyebab kematian tertinggi ke-2 pada kelompok umur 45-54 tahun di perkotaan (14,7\%) dan tertinggi ke-6 di daerah pedesaan $(5,8 \%)$. Diabetes melitus merupakan suatu kumpulan gejala yang yang disebabkan oleh adanya peningkatan kadar glukosa darah akibat kekurangan insulin baik absolut maupun, relative (Perkeni, 2015). Estimasi jumlah penderita diabetes Melitus, Indonesia menempati urutan ke-4 dari 10 besar negara dengan penderita diabetes terbanyak tahun 2000 dan 2030 (Infodatin 2019). Angka kejadian kota Depok menempati urutan kedua setelah infeksi saluran nafas atas, yaitu sebanyak 34.832 kasus $(11,76 \%)$.

Berdasarkan kondisi tersebut diabetes mellitus menjadi fokus perhatian comorbid yang harus dikendalikan agar tidak terpapar kasus covid 19 karena akan memperberat gejalanya. Peran masyarakat menjadi sangat penting untuk dapat mengendalikannya. Peran tersebut dapat dilakukan oleh kader kesehatan yang memang lebih dekat kepada masyarakat seperti keberadaan Pos Binaan Terpadu (Posbindu) yang memiliki kegiatan memonitor dan mendeteksi dini faktor resiko penyakit tidak menular salah satunya adalah diabetes mellitus. Posbindu Dahlia Senja merupakan Posbindu yang dibentuk di wilayah kelurahan Limo Kota Depok dalam hal salah satunya adalah upaya promosi kesehatan. Selama kondisi pandemic covid 19 hampir semua kegiatan pelayanan posbindu dibatasi. Sehingga kegiatan yang biasanya rutin dilakukan dalam mendeteksi dan memonitor kesehatan masyarakat terhenti karena khawatir meningkatkan penyeberan penyakit covid 19. Berdasarkan kondisi tersebut maka perlu dilakukan pelatihan kepada kader kesehatan untuk dapat tetap melaksanakan program programnya walaupun dalam situasi pandemic yaitu dengan dilakukannya pelatihan edukasi kader kesehatan dalam pengelolaan pasien diabetes mellitus dimasa pandemic covid 19.

\section{METODE PELAKSANAAN PKM}

Metode pelaksanaan dalam kegiatan pengabdian masyarakat ini adalah dalam bentuk pelatihan memberikan edukasi tentang pengelolaan pasien diabetes Melitus dimasa pandemic Covid 19. Tahap persiapan dilakukan dengan menghimpun materi diabetes melitus pada masa pandemic covid 19 untuk membuat poster sebagai media edukasi, mengkaji bahwa setiap peserta memiliki gadget yang nantinya akan dijadikan alat edukasi. Tahap pelaksanaan dilakukan dengan melakukan pre test sebelum kegiatan materi edukasi, kemudian memberikan penyuluhan dan demonstrasi edukasi kepada kader kesehatan melalui mini seminar secara virtual. Materi yang disampaikan pada mini seminar tersebut adalah tentang penyakit diabetes melitus dan protokol kesehatan selama pandemic covid 19 yang nantinya akan menjadi materi kader dalam menyampaikan edukasi. Kemudian dalam kegiatan ini pengabdi menyiapkan beberapa poster digital yang akan dijadikan alat media edukasi para kader melakukan edukasi selama masa pandemik melalui grup - grup media sosial. Mereview hasil pelatihan yang diberikan dengan memberikan post test dari materi yang sudah diberikan.Tahap evaluasi memonitor kegiatan posbindu setiap sebulan sekali dalam pelaksanaan edukasi pengelolaan pasien diabetes melitus pada masa pandemic covid 19. 


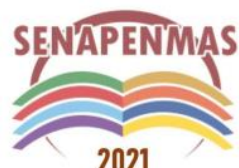

2021
Seminar Nasional Hasil Penelitian dan Pengabdian Kepada Masyarakat 2021

Pengembangan Ekonomi Bangsa Melalui Inovasi Digital Hasil Penelitian dan Pengabdian Kepada Masyarakat Jakarta, 21 Oktober 2021

\section{HASIL DAN PEMBAHASAN}

Tabel 1.Disribusi Karakteristik Kader Kesehatan

Berdasarkan Usia, lama pengalaman menjadi kader,kepemilikan gadget, Tahun 2021 (n=18)

\begin{tabular}{lll}
\hline Variabel & Mean & Min-Max \\
\hline Usia & 58,05 & $51-74$ \\
\hline $\begin{array}{l}\text { Lama Pengalaman } \\
\text { menjadi kader }\end{array}$ & 6,9 & $1-20$ \\
\hline Variabel & $\mathrm{n}$ & $\%$ \\
\hline Kepemilikan Gadget & 18 & 100 \\
\hline
\end{tabular}

Berdasarkan tabel 1 diatas katakterisktik usia kader kesehatan rata rata berusia 58 tahun dengan usia paling rendah 51 tahun dan paling tinggi 74 tahun dan rata rata lama pengalaman menjadi kader kesehatan adalah 6,9 tahun dengan paling rendah adalah 1 tahun dan paling lama adalah 20 tahun, serta semua kader kesehatan memiliki gadget.

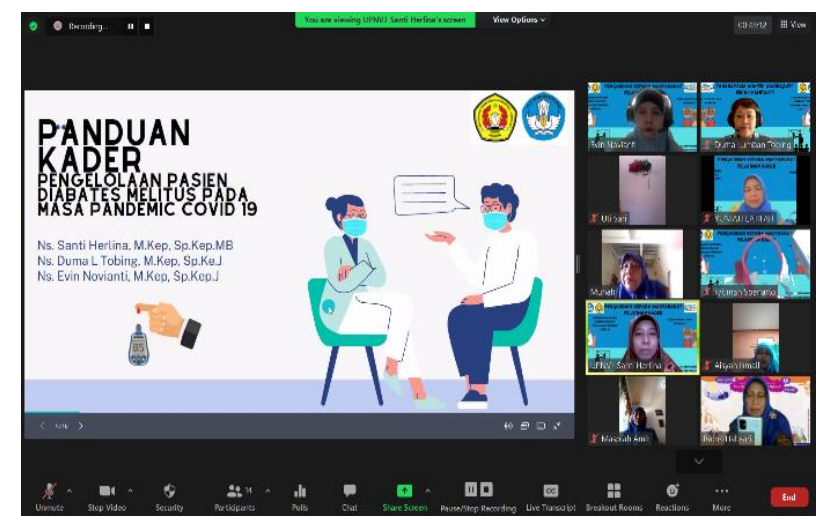

Gambar 1. Kegiatan pelatihan edukasi secara virtual

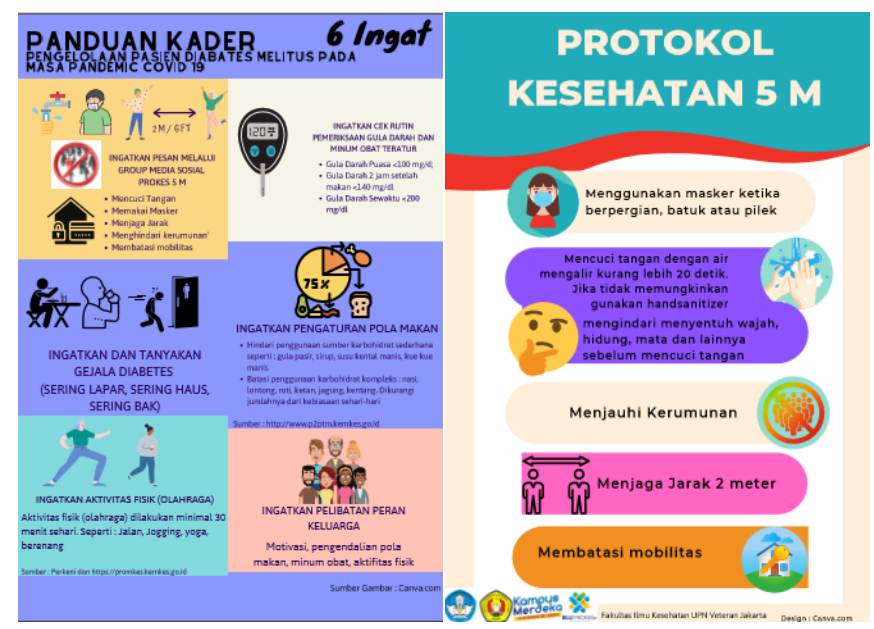




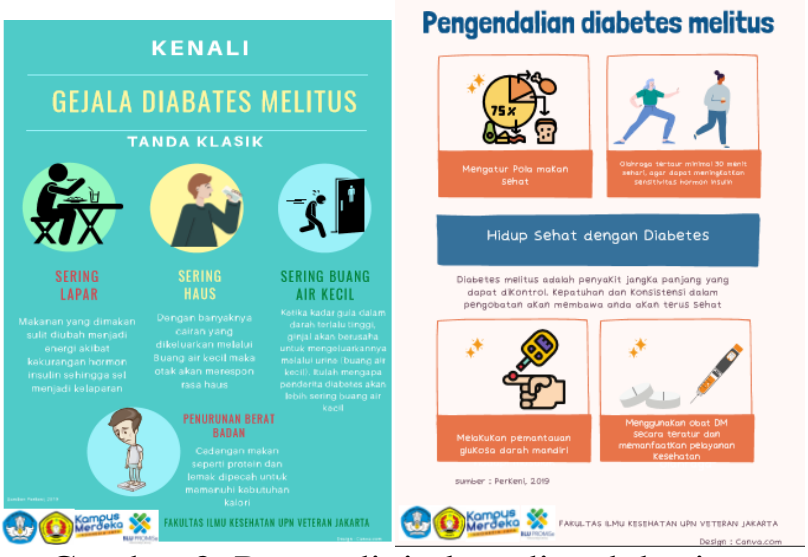

Gambar 2. Poster digital media edukasi

Tabel 4. Pengetahuan kader sebelum dan sesudah dilakukan pelatihan edukasi pengelolaan pasien diabetes mellitus dimasa pandemic covid $19(\mathrm{n}=18)$

\begin{tabular}{llll}
\hline Variabel & n & Mean & Min-Max \\
\hline $\begin{array}{l}\text { Pengetahuan sebelum } \\
\text { pelatihan }\end{array}$ & 18 & 69,70 & $55-82$ \\
$\begin{array}{l}\text { Pengetahuan setelah } \\
\text { pelatihan }\end{array}$ & 18 & 74,55 & $55-100$ \\
\hline
\end{tabular}

Berdasarkan tabel 4 diatas terlihat bahwa pengetahuan kader kesehatan sebelum pelatihan dan sesudah pelatihan menunjukkan terdapat peningkatan. Sebelum dilakukan pelatihan rata rata pengetahuan kader sebesar 69,70 dengan nilai paling rendah adalah 55 dan paling tinggi 82 . Sedangkan setelah dilakukan pelatihan rata rata pengetahuan kader meningkat sebesar 74,55 dengan nilai paling rendah adalah 55 dan paling tinggi 100. Hal ini sejalan dengan pengabdian kepada masyarakat Setyani, dkk (2021) tentang edukasi dan pendampingan kader tentang manajemen diri lansia dengan komorbid diabetes mellitus di era pandemic covid 19 menunjukkan bahwa terdapat perbedaan rata-rata hasil pre-test dan post-test. Rata-rata nilai pretest kader adalah 70,4 dan post-test 76,5. Selisih nilai pre-test dan post-test adalah 6 poin. Sedangkan pada pengabdian ini terdapat selisih 4,85.

Era saat ini semua orang begitu mudah mendapatkan informasi apapun, karena hampir setiap orang memiliki gadget dalam berinteraksi. Pada data didapatkan setiap kader memiliki gadget. Dengan kondisi pandemik covid 19, hal ini dapat dimanfaatkan untuk penyampaian edukasi yang tidak memerlukan tatap muka secara langsung. Kegiatan edukasi dapat dilakukan rutin dengan pembagian jadwal share informasi melalui poster digital tersebut melalui media sosial grup komunitasnya. Hal ini diharapkan dapat memotivasi pasien diabetes mellitus dalam mematuhi program pengobatan dan pengendalian penyakitnya serta menjaga agar tidak terpapar covid 19. Salah satu materi yang disampaikan adalah terkait dengan protokol kesehatan agar penderita diabetes melitus tidak terpapar covid 19. Diabetes mellitus adalah salah satu komorbid yang banyak terjadi pada kasus covid 19. Berdasarkan hasil pengabdian kepada masyarakat yang dilakukan Sudarsono, dkk (2021) menunjukkan penggunaan video dan edukasi digital melalui WA dapat menjadi alternatif sebagai media edukasi pasien di masa pandemi.

Tingginya angka kematian covid 19 dikarenakan penyakit cormobid, diabetes melitus merupakan penyakit multisistem kronis dengan kondisi tubuh tidak dapat memproduksi insulin secara normal sehingga terjadi peningkatan kadar glukosa darah (Harding dkk., 2020). Pemeriksaan kadar glukosa darah dibagi menjadi tiga, yaitu kadar glukosa darah puasa, sewaktu, dan setelah makan. Kadar glukosa darah puasa diukur setelah tidak makan 8 jam dan dikatakan diabetes 
melitus jika nilai glukosa darah > $126 \mathrm{mg} / \mathrm{dL}$. Sedangkan, kadar glukosa darah sewaktu diukur tanpa puasa dan nilai glukosa darah > $200 \mathrm{mg} / \mathrm{dL}$ akan dikatakan diabetes melitus. Sejalan dengan itu, nilai glukosa darah > $200 \mathrm{mg} / \mathrm{dL}$ juga menjadi indikator diabetes melitus pada pengukuran glukosa darah dua jam setelah makan (Black \& Hawks, 2014). Sehingga edukasi melalui media sosial akan menjadi efektif selama masa pandemic covid 19 ini dalam mengendalikan diabetes mellitus yang merupakan salah satu komorbid.

\section{KESIMPULAN}

Pengendalian covid 19 memerlukan banyak peran untuk mengatasinya. Dengan kondisi keterbatasan mobilitas akibat pandemik tidak menjadikan aktivitas terhenti. Edukasi menjadi sangat mudah apabila dapat memanfaat teknologi yang banyak ditawarkan. Pengelolaan pasien diabetes mellitus dapat dilakukan melalui edukasi kader kesehatan melalui media sosial dengan memberikan informasi kesehatan melalui poster digital yang dapat dishare secara rutin melalui media sosial grup komunitasnya. Pelatihan ini memiliki pengaruh yang baik dalam meningkatkan pengetahuan dan kemampuan kader sehingga diharapkan kader dapat tetap memberikan edukasi kepada pasien yang memiliki riwayat diabetes mellitus walaupun dalam situasi pandemic covid 19.

\section{Ucapan Terimakasih (Acknowledgement)}

Ucapan terimakasih penulis sampaikan kepada UPN Veteran Jakarta yang telah memfasilitasi kegiatan Pengabdian Kepada Masyarakat. Ucapan terimakasihpun penulis sampaikan kepada Rektor UPN Veteran Jakarta, Ketua LPPM UPN Veteran Jakarta, Dekan FIKES UPN Veteran Jakarta, Ketua dan para kader Posbindu Dahlia Senja Kelurahan Limo Kota Depok

\section{REFERENSI}

Black, J.M., \& Hawks. J.H. (2014). Keperawatan Medikal Bedah : Manajemen klinis untuk hasil yang diharapkan. Elsevier (Singapore)

Harding, M. M., Kwong, J., Roberts, D., \& Hagler, D. (2020). LEWIS'S MEDICAL-SURGICAL NURSING, ELEVENTH (11th ed.). Elsevier Inc.

PERKENI. (2015). Pengelolaan dan Pencegahan Diabetes Melitus Tipe 2 di Indonesia. Jakarta: PERKENI

Kementerian Kesehatan RI. (2019). INFODATIN: Pusat Data dan Informasi : Hari Diabetes Sedunia Tahun 2018. Jakarta: Badan Litbangkes Kemenkes RI

Kementrian Kesehatan RI. (2018). Hasil Utama Riskesdas 2018. Jakarta: Badan Penelitian dan Pengembangan Kesehatan Kemenkes RI

Satuan Tugas Penanganan Covid 19 per tanggal 7 September 2021 jam 14.15 di www.covid19.go.id

Setyani, Dewi dkk (2021). Edukasi dan pendampingan kader tentang manajemen diri lansia dengan komorbid diabetes melitus pada era pandemi covid-19 di Kelurahan Sidanegara Kabupaten Cilacap. Indonesia Berdaya, 2(1): 41 - 46. https://doi.org/10.47679/ib.202167

Sudarsono, Joko dkk (2021). Modifikasi Model Edukasi di Masa Pandemi untuk Menjaga Ketaatan Diet dan Minum Obat Pasien Diabetes Melitus.. AgriHealth: Journal of Agrifood, Nutrition and Public Health. 2(1), 17-22, 2021. DOI: http://dx.doi.org/10.20961/agrihealth.v2i1.48804

Yang, X., Yu, Y., Xu, J., Shu, H., Xia, J., Liu, H., Wu, Y., Zhang, L., Yu, Z., Fang, M., Yu, T., Wang, Y., Pan, S., Zou, X., Yuan, S., \& Shang, Y. (2020). Clinical course and outcomes of critically ill patients with SARS-CoV-2 pneumonia in Wuhan, China: a single-centered, retrospective, observational study. The Lancet Respiratory Medicine, 8(5), 475-481. https://doi.org/10.1016/S2213-2600(20)30079-5 
Seminar Nasional Hasil Penelitian dan Pengabdian Kepada Masyarakat 2021

Pengembangan Ekonomi Bangsa Melalui Inovasi Digital Hasil Penelitian dan

Pengabdian Kepada Masyarakat

Jakarta, 21 Oktober 2021

(halaman kosong) 